\title{
New ways of working and work engagement
}

\author{
Citation for published version (APA):
}

Baudewijns, C., Gerards, R., \& de Grip, A. (2015). New ways of working and work engagement. Maastricht University, Graduate School of Business and Economics. GSBE Research Memoranda No. $006 \mathrm{https}: / /$ doi.org/10.26481/umagsb.2015006

Document status and date:

Published: 01/01/2015

DOI:

10.26481/umagsb.2015006

Document Version:

Publisher's PDF, also known as Version of record

\section{Please check the document version of this publication:}

- A submitted manuscript is the version of the article upon submission and before peer-review. There can be important differences between the submitted version and the official published version of record.

People interested in the research are advised to contact the author for the final version of the publication, or visit the DOI to the publisher's website.

- The final author version and the galley proof are versions of the publication after peer review.

- The final published version features the final layout of the paper including the volume, issue and page numbers.

Link to publication

\footnotetext{
General rights rights.

- You may freely distribute the URL identifying the publication in the public portal. please follow below link for the End User Agreement:

www.umlib.nl/taverne-license

Take down policy

If you believe that this document breaches copyright please contact us at:

repository@maastrichtuniversity.nl

providing details and we will investigate your claim.
}

Copyright and moral rights for the publications made accessible in the public portal are retained by the authors and/or other copyright owners and it is a condition of accessing publications that users recognise and abide by the legal requirements associated with these

- Users may download and print one copy of any publication from the public portal for the purpose of private study or research.

- You may not further distribute the material or use it for any profit-making activity or commercial gain

If the publication is distributed under the terms of Article $25 \mathrm{fa}$ of the Dutch Copyright Act, indicated by the "Taverne" license above, 


\section{Maastricht University}

Claudia Baudewijns,

Ruud Gerards, Andries de Grip

New Ways of Working and Work Engagement

RM/15/006

\section{GSBE}

Maastricht University School of Business and Economics

Graduate School of Business and Economics

P.O Box 616

NL- 6200 MD Maastricht

The Netherlands 


\title{
New Ways of Working and Work Engagement.
}

\section{Claudia Baudewijns}

School of Business and Economics, Maastricht University, Netherlands; c.baudewijns@alumni.maastrichtuniversity.nl; Department of Economics, P.O. Box 616, NL6200 MD Maastricht, The Netherlands; phone +31 43 3883821; fax +31 433882000.

Ruud Gerards (corresponding author)

ROA, NSI, Department of Economics and CofFEE-Europe, Maastricht University; e-mail R.Gerards@maastrichtuniversity.nl; ROA, Maastricht University, Netherlands, P.O. Box 616, NL-6200 MD Maastricht, The Netherlands; phone +31 43 3883647; fax +31 433884914.

\section{Andries de Grip}

ROA, Maastricht University, Netherlands and IZA, Bonn, Germany. A.deGrip@maastrichtuniversity.nl; ROA, P.O. Box 616, NL-6200 MD Maastricht, The Netherlands; phone +31 43 3883647; fax +31 433884914 .

Running title: New Ways of Working and Work Engagement

\begin{abstract}
This article investigates whether New Ways of Working (NWW) are related to employee work engagement in the Netherlands. We test our hypotheses using a sample of 656 employees from 14 industry sectors and 12 occupational fields. Our study reveals that three facets of NWW positively affect work engagement: "manage your own work," "unlimited access and connectivity," and "open workplace." The effects of "open workplace" and "unlimited access and connectivity" on work engagement appear to be fully mediated by the combination of social interaction and transformational leadership. Managing your own work is however not mediated by social interaction or transformational leadership. As such, it is the only facet of NWW that directly affects work engagement. Our results hold important practical implications for organizations that consider implementing NWW. To maximize the positive impact of NWW on work engagement, while keeping the cost of introducing NWW to a minimum, firms should take
\end{abstract}


account of the abilities and preferences of their line managers with respect to transformational leadership. Depending on these, a limited or more comprehensive set of NWW facets may be most efficient at promoting work engagement.

Keywords: work engagement, new ways of working, social interaction, transformational leadership

\section{Acknowledgements}

We thank Roger Schils, Evert Webers and Eric Schlosser of RMI/IBC for their assistance in the survey design. We thank Marion Collewet and Jol Stoffers for their helpful comments on an earlier version of this paper. 


\section{Introduction}

Enabled by rapid advances in information and communications technology, human resource management practices associated with New Ways of Working (NWW) are a recent phenomenon in work organizations. NWW allows employees to flexibly organize their work. However, there are few studies on the effects of NWW on employee outcomes (Blok, Groenesteijn, Schelvis \& Vink, 2012; Demerouti, Derks, Ten Brummelhuis \& Bakker, 2014; Peters, Poutsma, Van der Heijden, Bakker \& Bruijn, 2014), and little is known about the impact of NWW on employee work engagement.

To our knowledge, Ten Brummelhuis, Bakker, Hetland, and Keulemans (2012) is the only study that analyzes the relation between NWW and work engagement. Ten Brummelhuis et al. (2012) conclude that NWW has the potential to boost work engagement by increasing employee process control and facilitating more efficient communication among colleagues. However, their study is based on employees in a single firm, which leads these authors to recommend future research to study the generalizability of the relationship between NWW and work engagement.

With the present paper, we answer their call and add to the literature on NWW in several ways. First, we examine the impact of several aspects of NWW on work engagement of employees from 14 industry sectors and 12 occupational fields. We build on Peters et al. (2014), who investigate the impact of NWW on "work-related flow" (absorption in work, work enjoyment, and intrinsic work motivation) in a few specific job categories across multiple organizations. This makes our paper the first to study the effects of NWW on work engagement using a sample of an entire country's (The Netherlands) working population.

Second, we use a comprehensive definition of NWW, including five individual facets. We estimate a model in which these five facets are aggregated into one, as well as models that distinguish the individual facets. Building on the current literature, we distinguish the following five facets of NWW: (1) time and location independent working ("any time, anywhere"), (2) management on output ("manage your own work"), (3) free accessibility and use of knowledge and ideas ("unlimited access and connectivity"), (4) flexibility in working relations ("my size fits me"), and (5) freely accessible open workplaces (“open workplace") (Baane, Houtkamp \& Knotter, 2010; Bijl, 2009; Graham, 2004; Halford, 2005). These facets are constructed from various underlying items (see Appendix A). Current studies in the work engagement literature 
include only single facets or less comprehensive definitions of NWW, such as flexible time and place, new media technologies (Deci, Ryan, Gagné, Leone, Usunov \& Kornazheva, 2001; Ten Brummelhuis et al., 2012), and increased levels of autonomy (Bakker \& Bal, 2010; Bakker, Albrecht \& Leiter, 2011a; Mauno, Kinnunen \& Ruokolainen, 2007; Salavona \& Agut, 2005). Using our comprehensive definition of NWW, we are able to disentangle in which positive or negative direction the various facets of NWW contribute to the overall effect of NWW on work engagement.

Third, building on De Leede and Kraijenbrink (2014), we take account of two potential mediators between (facets of) NWW and work engagement: social interaction at work and the extent to which managers exhibit transformational leadership. Although De Leede and Kraijenbrink (2014) acknowledge that leadership needs to be taken into account when studying the effects of NWW, and some authors even incorporate it into their analyses (e.g., Peters et al., 2014), who include "supporting leadership"), we are the first to consider "transformational leadership" as a mediator between NWW and work engagement.

Our results hold important practical implications for organizations that consider implementing NWW. To maximize the positive impact of NWW on work engagement, while keeping the cost of introducing NWW to a minimum, firms should take account of the abilities and preferences of their line managers. Depending on these, a limited or more comprehensive set of NWW facets may be most efficient at promoting work engagement.

This paper proceeds as follows. Section 2 briefly discusses the literature on work engagement and the literature on the five facets of NWW we identify, along with social interaction at work and transformational leadership. From this literature, we derive our empirical model and hypotheses. Section 3 describes our data and variables of interest. In Section 4, we present our estimation results. Section 5 concludes by discussing our main outcomes.

\section{Literature}

\section{Work engagement}

Schaufeli, Salanova, González-Romá and Bakker (2002, p. 74) characterize engaged employees as having a "positive, fulfilling, work-related state of mind characterized by vigor, dedication, 
and absorption." Employee engagement has been shown to relate positively to various outcomes relevant for organizational performance as well as employee well-being. Various studies show that organizations are more likely to exceed their industry's average revenue growth, employee retention, and customer loyalty if their employees are more engaged (e.g., Harter, Schmidt \& Hayes, 2002; Markos \& Sridevi, 2010). In addition, work engagement is positively related to organizational commitment (Yalabik, Rossenberg, Kinnie and Swart, forthcoming) and, more generally, to positive organizational behavior (e.g., Bakker \& Schaufeli, 2008; Bakker, Albrecht \& Leiter, 2011b). Finally, work engagement is positively associated with employee well-being (Demerouti, Bakker, de Jonge, Janssen \& Schaufeli, 2001; Hakanen \& Schaufeli, 2012; Rothbard, 2001; Schaufeli, Salanova, Gonzalez-Roma \& Bakker, 2002).

Baumruk (2006) sheds more light on the underlying mechanisms by which work engagement affects organizational outcomes. This author identifies three different ways in which engaged employees improve organizational performance. These general behaviors are referred to as "say, stay, and strive." If employees are engaged, they will advocate the organization to coworkers, and promote the organization to potential employees and customers ("say"). Moreover, the desire to be a member of the organization will connect engaged employees despite job offers from other firms ("stay"). Furthermore, engaged employees will contribute to the success of the business by exerting extra time, effort, and initiative ("strive").

Despite a vast body of literature on the consequences of work engagement (see Bakker, Schaufeli, Leiter and Taris, 2008, for an overview) there is little empirical research investigating the determinants of work engagement. Moreover, the relation between human resource management practices and work engagement has only recently gained attention (Truss, Shantz, Soane, Alfes \& Delbridge, 2013). Saks (2006) finds that employee engagement is enhanced by jobs that offer challenging work and variety, that allow for use of a variety of skills and personal discretion, and that afford the opportunity to meaningfully contribute. Furthermore, this author finds that procedural justice contributes to increased employee engagement; "procedural justice" refers to "the perceived fairness of means and processes used to determine the amount of distribution and resources" (Saks, 2006, p. 606). As shown in the next subsection, NWW includes several of these job characteristics and it fosters procedural justice. 


\section{NWW}

Several authors note that the scientific literature on NWW remains scarce (e.g., Blok, Groenesteijn, Van Den Berg \& Vink, 2011; De Leede \& Kraijenbrink, 2014; Ten Brummelhuis et al., 2012). Most studies on NWW originate from general business literature and use a variety of definitions and measurements of NWW. For instance, Bijl (2009), considers NWW as practices that center the organization around its employees, providing them, within certain boundaries, with the freedom to determine how, where, and when they work, and to decide which resources they use and with whom they work. According to this definition, NWW can be considered "new," as it centers on employees, while traditional HR practices focus on facilitating the production process. We use a more comprehensive definition derived from multiple studies. Our definition of NWW includes five facets: (1) time- and location-independent working, (2) management on output, (3) free accessibility and use of knowledge and ideas, (4) flexibility in working relations, and (5) freely accessible, open workplaces.

The first NWW facet refers to working independent of time and place, which we refer to as: "any time, anywhere" (Baane et al., 2010). Halford (2005) illustrates this facet by quoting several phrases from an employee of a large UK-based financial services company: "Sometimes you think, 'Oh I really need to get this done, I'll go home' ..... 'so it's nice in a way that you have got somewhere you can go and work in quiet."' (p. 26).

The second NWW facet refers to management on output or performance rather than management of how employees conduct their work. Baane et al. (2010, p. 42) refer to this NWW facet as "manage your own work." The third facet refers to free access and use of organizational knowledge, experience, and ideas. Following Baane et al. (2010), we label this facet "unlimited access and connectivity." The fourth NWW facet is based on what Reynaarde Talent Development (2013) describes as a shift from "one size fits all" to "my size fits me." This refers to practices that allow employees to accommodate their working life in such a way that it fits with their current private situation. The fifth NWW facet is derived from studies that emphasize the interplay between the physical and mental environments. Graham (2004) argues that employee behavior to some extent always depends on physical elements of the workplace. Organizations with NWW facets often refurbish offices into freely accessible, open workplaces. These freely accessible workplaces are intended to minimize physical and mental distance via 
stimulating encounters and cooperation among colleagues. ${ }^{1}$ Following Halford (2005), we label this fifth facet of NWW the "open workplace."

According to Ten Brummelhuis et al. (2012), NWW has the potential to boost work engagement by (1) increasing employee process control, and (2) fostering efficient communication among colleagues. Moreover, several studies show that increased worker autonomy leads to higher levels of work engagement (Bakker \& Bal, 2010; Mauno, Kinnunen \& Ruokolainen, 2007; Salanova \& Agut, 2005). Likewise, Bakker et al. (2011b) propose that employees who manage their own work increase their job challenges and job resources, and subsequently remain more engaged.

Although it appears that most studies expect mainly positive impacts of NWW on work engagement, the question remains whether certain elements of NWW, such as the ability to work at any time and anywhere, resulting in always being electronically connected, may reduce work engagement (De Leede \& Kraijenbrink, 2014). This potential negative consequence of NWW is anecdotally underlined by recent policy changes in several German firms, such as Volkswagen and Deutsche Telekom, that place restrictions on after-hours e-mail and phone connectivity, to protect workers from burnout. Although we acknowledge this potentially negative impact of NWW on work engagement, in sum, we must conclude that the vast majority of relevant literature expects NWW relates positively to the work engagement. Therefore, our first "default" hypothesis is:

Hypothesis 1. All five facets of NWW are positively related to work engagement.

\section{Social interaction at work}

Social interaction at work refers to mutual trust, personal networks, and communities (Prusak, 2001). A supportive social environment is beneficial for organizations, as it fosters valuable resource collaboration, leading to positive work attitudes (Bakker, Demerouti, \& Verbeke, 2004). Social interaction is likely to be affected by NWW. One of the facets that is likely to affect social interaction is "any time, anywhere," although the expected sign of the effect is not

\footnotetext{
${ }^{1}$ De Souza e Silva (2006) takes a slightly different viewpoint, arguing that there is no longer a distinction between digital and physical space. Therefore, it is not necessary to refurbish offices into open workplaces, since IT solutions already foster encounters between colleagues.
} 
unambiguously clear from the literature. Gajendran and Harrison (2007) find a positive correlation between telecommuting and the quality of the employee-supervisor relationship, but these authors do not find a relation between telecommuting and the quality of co-worker relationships. Similarly, Duxbury and Neufeld (1999) find no decrease in effective communication on the part of employees who switched to working partially outside the office. However, several other studies show negative effects from working outside the office on social interaction at work (Cooper \& Kurland, 2002; Morganson, Major, Oborn, Verive \& Heelan, 2010). Working outside the office increases the potential of social isolation, which, in turn, increases the potential of burnout (Kilgore \& Griffin, 1998; Miller, Brownell, \& Smith, 1999; Rosenberg, O’Shea \& O'Shea, 1998). Finally, De Leede and Kraijenbrink (2014), studying a Dutch insurance firm, find that social cohesion, which is related to social interaction, mediates the relation between NWW and self-assessed productivity of employees. Based on these studies, we hypothesize that social interaction at work mediates the relationship between NWW facets and work engagement, as follows:

Hypothesis 2. Social interaction mediates the relationship between NWW and work engagement.

\section{Transformational leadership}

Managers face various challenges when working with facets of NWW. According to De Leede and Kraijenbrink (2014), a big challenge for managers is the switch from direct supervision to managing based on output, which is a key consequence of NWW, since managers simply no longer see their employees on a daily basis. Moreover, when employees work in the office, they manage their own work in an open workplace; this also requires managing based on output. This requires transformational leadership that elevates workers' concerns for achievement (Bass, 1999). De Leede and Kraijenbrink (2014) include a four-item scale on "result-oriented leadership" in their analysis, but are unable to use it as a mediator due to a low Cronbach's alpha. In their study on the relation between NWW and work-related flow, Peters et al. (2014) also take into account the role of leadership. These authors include a five-item scale measuring "supporting leadership." However, they do not test for a mediating role of this leadership measure; rather, they consider it an element of NWW. 
Since there are also studies showing that transformational leadership is positively related to work engagement (Babcock-Roberson \& Strickland, 2010; Bakker et al., 2011b; Breevaart, Bakker, Hetland, Demerouti, Olsen, \& Espevik, 2014; Rowden, 2000; Zhu, Avolio, \& Walumbwa, 2009), we expect transformational leadership to be a mediator between NWW and work engagement.

Hypothesis 3. Transformational leadership mediates the relationship between NWW and work engagement.

Figure 1 gives an overview of the hypothesized relationships between NWW facets and work engagement.

Insert Figure 1 about here

\section{Data and Measurements}

For our empirical analysis, we use survey data from a representative panel of Dutch households collected by RMI (a full-service market research company). ${ }^{2}$ Our questionnaire (See Appendix A) was sent to 15,491 panel members in June 2013. The survey resulted in 901 responses (a 5.8\% response rate). To focus on employees, we exclude entrepreneurs from our sample, resulting in a data set of 703 employees. Further, we exclude 47 employees for which we could not construct the fifth facet "open workplace," as they reported that they do not work in a building (e.g., truck, taxi, and train drivers, postal deliverers). Appendix B shows the demographic characteristics of the final sample of 656 employees. Partly due to the fact that those who do not work in a building are excluded, females and workers with higher education are over-represented in the final sample.

To measure work engagement, we use the nine-statement version of the "Utrecht work engagement scale" (Schaufeli \& Bakker, 2003). Respondents were asked to rate the nine statements on a seven-point scale, ranging from "never" to "always." All items are listed in Appendix A.

\footnotetext{
${ }^{2}$ See www.het-internet-panel.nl
} 
To measure the extent to which employees work with NWW, we developed a set of 10 items that together cover the five NWW facets. ${ }^{3}$ All items on this scale are rated on a five-point scale ranging from "not at all" to "to a very high degree." An overview of all items used to measure the five facets of NWW is presented in Appendix A.

We measure social interaction at work by four statements derived from Van Veldhoven \& Meijman (1994) and Golden (2006). Example statements include "Communication by means of face-to-face contact is important to maintain a good working relationship," and "I find working with my colleagues pleasant." All statements are rated on a five-point scale, ranging from "not at all" to "to a very high degree."

Transformational leadership is measured on both emotional quotient and spiritual quotient, using a set of items derived from Bass (1991), Robbins \& Judge (2007) and Bijl (2009). Managers who use emotional quotient practices focus on asking questions, and display increased awareness of others. Examples of statements we use are: "my supervisor provides guidance when I need it," and "my supervisor considers the individual." Transformational leadership based on spiritual quotient provides inspirational motivation to employees. Example statements for transformational leadership based on spiritual quotient are: "my supervisor inspires and motivates employees," and "my supervisor gives a clear image of his strategic vision." All these statements are rated on a five-point scale, ranging from "not at all" to "to a very high degree." A full list of statements used is presented in Appendix A.

Table 1 shows the correlation between our variables and the Cronbach's alpha coefficients for all constructs included in our analysis. NWW as an aggregate variable including all 10 items, the separate items of NWW, work engagement and transformational leadership, all show an internal consistency that is approximately at the preferred level of $0.80 .{ }^{4}$ The internal consistency of social interaction at work shows an alpha of 0.74 , which is still an acceptable value (Peterson, 1994). We standardized these variables to a mean of zero and standard deviation of 1 .

Insert Table 1 about here

\footnotetext{
${ }^{3}$ Some items are based on the Maastricht Autonomy Questionnaire (MAQ), developed by De Jonge, Landeweerd, and Van Breukelen (1994).

${ }^{4}$ Facets 2 and 4 refer to only one item.
} 


\section{Results}

We first test a multiple mediation model in which we take the aggregate NWW variable as the independent variable. We apply the Preacher and Hayes (2008) bootstrap method for multiple mediators and control variables. We estimate the model with various control variables, such as age, gender, education level, sector of industry, and occupational field. Figure 2 summarizes our findings within the framework of the model we analyze. The figure shows that NWW has a significant, positive effect on work engagement (panel A, which shows the total effect (c)). Panel B presents a decomposition of the total effect into the direct effect $\left(c^{\prime}\right)$ of NWW on work engagement and the indirect effects $\left(a_{i} * b_{i}\right)$, which run through social interaction and transformation leadership. Panel B shows that social interaction and transformational leadership both positively mediate the relationship between NWW and work engagement, and that there remains a positive direct effect of NWW on work engagement, which indicates that there is only partial mediation. All findings are significant at the $1 \%$ level.

Appendix $\mathrm{C}$ presents bootstrap results and shows the coefficients of the indirect effects as well as the standard errors, Z-values, and confidence intervals. The indirect effect (0.26) is much larger than the direct effect $(0.17$, see Figure $2 \mathrm{~B})$, and the part of the total effect (c) that is mediated is well over half (total indirect effect 0.26 / total effect $0.43=0.60$ ).

Insert Figure 2 about here

Next, we test several models that simultaneously take into account the five separate facets of NWW as well as social interaction and transformational leadership. For consistency, we apply the same set of control variables to all estimations. We use ordinary least squares to estimate our models, since the dependent variables social interaction, transformational leadership, and work engagement are standardized constructs based on several underlying items, the dependent variables therefore take a continuous form. Following Alfes, Shantz, Truss and Soane (2013), we test for mediation using the steps outlined by Baron and Kenny (1986). Table 2 presents our estimation results. Columns 1 and 2 test whether the NWW facets are correlated with the mediators "social interaction" and "transformational leadership," respectively. The table shows that the NWW facets "unlimited access and connectivity" and "open workplace" are correlated 
with both mediators. Further, the facet "any time, anywhere" is correlated with "transformational leadership." These highly significant correlations between the independent variable(s) and the mediators prove the first necessary condition for mediation.

Columns 3, 4, and 5 provide evidence for the next two conditions to establish mediation, and they provide evidence on Hypothesis 1. Columns 3 and 4 show that both mediators are significantly related to work engagement, whereas Column 5 shows that three of the five NWW facets are significantly related to work engagement. This holds for the NWW facets "unlimited access and connectivity" and "open workplace" (which are also related to the two mediating variables), as well as for the facet "manage your own work." Hence, three out of five facets of NWW are positively related to work engagement, providing partial support for Hypothesis 1, which predicts a positive relation for all five facets.

In the final step toward establishing mediation, we estimate three models, which simultaneously include one or both of the mediators and all independent variables. Column 6 shows the estimation results when including social interaction as a mediating variable; its inclusion renders the coefficients of the NWW facets "unlimited access and connectivity" and "open workplace" insignificant. This shows that social interaction fully mediates these two NWW facets. However, the NWW facet "manage your own work" remains highly significant and positively related to work engagement. Taken together, these results partly support Hypothesis 2, which predicts a mediating role for social interaction between NWW facets and work engagement.

Column 7 includes the mediator "transformational leadership." Its presence lowers both the significance and size of the coefficient of "unlimited access and connectivity," indicating partial mediation. Further, it renders the coefficient of "open workplace" insignificant, establishing full mediation on this variable. However, the coefficient for "manage your own work" remains highly significant. Together, these results provide partial support for Hypothesis 3, which predicts a mediating role between the NWW facets and work engagement.

Column 8 shows the estimation results when including both mediators. Both mediators remain highly significant. The only NWW facet to remain highly significant is "manage your own work"; moreover, the coefficient of this facet of NWW is hardly affected when including the mediators.

Insert Table 2 about here 


\section{Conclusions and Discussion}

We investigate whether NWW is related to employee work engagement. We contribute to the current literature on NWW in three ways. First, we study this relationship for a sample of a country's working population, comprising 14 sectors of industry and 12 occupational fields. This makes our paper one of the first studies on NWW that is generalizable beyond the single-firm level. Second, we use a comprehensive definition of NWW, including five different facets, and estimate a model in which these five facets of NWW are aggregated into one variable, as well as models that focus on the impact of individual NWW facets on work engagement. Third, we analyze whether social interaction at work, as well as the extent to which managers exhibit transformational leadership, are potential mediators between (facets of) NWW and work engagement.

Our analysis shows that, while controlling for age, gender, education, sector of industry, and occupational field, NWW as an aggregate concept is positively related to work engagement of employees in The Netherlands. This relationship is partially mediated by both social interaction and transformational leadership. Indirect effects account for $60 \%$ of the total effect, emphasizing the importance of social interaction and transformational leadership as conduits.

Our subsequent analysis, which focuses on the five separate facets of NWW, reveals that three facets of NWW positively affect work engagement: "manage your own work," "unlimited access and connectivity," and "open workplace," while the facets "any time, anywhere" and "my size fits me" are not significantly related to work engagement.

The positive relation between "open workplace" and work engagement appears to be fully mediated by social interaction in the workplace and transformational leadership. This suggests that an open workplace in itself does not promote employee engagement; rather, it is social interaction and transformational leadership, which an open workplace stimulates, that fosters work engagement. The effects of "unlimited access and connectivity" on work engagement are also fully mediated by social interaction, and partially by transformational leadership. The implications are akin to those for an open workplace. We conclude that social interaction and transformational leadership are important determinants of work engagement, whereas "unlimited access and connectivity" and "open workplaces" are effective ways of enhancing these 
determinants. Our analysis further shows that the NWW facet "manage your own work" is not mediated by social interaction or transformational leadership; as such, it is the only facet that directly affects work engagement.

\section{Practical implications}

Our finding that "manage your own work" is the only NWW facet that directly impacts employee work engagement, without being mediated, indicates that providing workers with more autonomy is a very effective way to increase their engagement. Complementary measures are not required to contribute to worker engagement. This finding is important for HR decision makers, as it shows that they do not need to implement a full suite of NWW facets to increase employee work engagement. When organizations consider implementing a more comprehensive suite of NWW facets, including creation of open workplaces and unlimited access and connectivity, our results show that such action would increase work engagement only if the organization is willing and able to foster transformational leadership and social interaction. These two practices fully mediate the effects of open workplaces and unlimited access and connectivity on employee work engagement, which suggests that transformational leadership and social interaction are necessary conduits for open workplaces and unlimited access and connectivity to make a difference.

On one end of the spectrum, there may be organizations where line managers are not able or willing to move toward a more transformational leadership style. Such organizations may benefit little from implementing a more comprehensive suite of NWW facets. However, even these organizations may still benefit from implementing the facet "manage your own work," since increased autonomy of workers directly affects work engagement without the need for supportive actions. On the other end of the spectrum, there may be organizations that foster social interaction in the workplace and in which line managers are both able and willing to adopt a more transformational leadership style, or they may already apply this management style. In such organizations, implementing a more comprehensive suite of NWW facets will probably have a larger impact on work engagement compared to implementing only "manage your own work," since through the mediating effects of increased transformational leadership and social interaction, open workplaces and unlimited access and connectivity further improve work engagement. 
Since most changes to organizations' working methods and habits, such as a move from a traditional way of working to NWW, are costly, time consuming, and may require substantial periods of adjustment, understanding the managerial abilities and preferences of line managers is important for HR decision makers considering implementing NWW. Thus, to maximize the positive impact of NWW on work engagement, while keeping the cost of introducing NWW to a minimum, firms should take account of the abilities and preferences of their line managers. Depending on these, a more limited or comprehensive set of NWW facets may be most efficient at promoting work engagement.

\section{Limitations and suggestions for further research}

The results of this study indicate several limiting factors that provide nuance to our findings and lead to recommendations for further research. First, by using cross-sectional data, we are not able to control for unobserved heterogeneity. Estimates of fixed-effects models on panel data could identify causal relationships. Second, our findings build on a data set on the Dutch working population. Cultural differences between working populations of different countries may restrict the external validity of our findings. Future research should, then, attempt to analyze the effects of NWW in an international setting, taking account of different cultural dimensions (e.g., those identified in the Hofstede cultural dimensions theory (Hofstede, 1980)). Third, our data set includes no information on the stage of implementation of the various NWW facets in the organization where the respondent is employed. Therefore, we cannot distinguish between employees who are used to working with particular NWW facets for several years and those who just started to work with particular facets, for example. Future research should account for the stages of implementation of the various NWW facets, either at the firm level or that of individual workers, by distinguishing between organizations that just introduced particular facets of NWW and similar firms that introduced NWW longer ago, or by distinguishing between workers who have recently begun working according to NWW as opposed to similar workers in similar organizations who have been working according to NWW for some time. 


\section{References}

Alfes, K., Shantz, A. D., Truss, C., \& Soane, E. C. (2013). The link between perceived human resource management practices, engagement and employee behaviour: a moderated mediation model. The International Journal of Human Resource Management, 24(2), 330-351.

Baane, R., Houtkamp, P., \& Knotter, M. (2010). Het Nieuwe Werken ontrafeld. Assen: Van Gorcum.

Babcock-Roberson, M. E., \& Strickland, O. J. (2010). The relationship between charismatic leadership, work engagement, and organizational citizenship behaviors. The Journal of Psychology, 144(3), 313-326.

Bakker, A. B., Albrecht, S. L., \& Leiter, M. P. (2011a). Key questions regarding employee engagement. European Journal of Work and Organizational Psychology, 20(1), 4-28.

Bakker, A. B., Albrecht, S. L., \& Leiter, M. P. (2011b). Work engagement: Further reflections on the state of play. European Journal of Work and Organizational Psychology, 20(1), 7488.

Bakker, A. B., \& Bal, M. P. (2010). Weekly work engagement and performance: A study among starting teachers. Journal of Occupational and Organizational Psychology, 83(1), 189-206.

Bakker, A. B., Demerouti, E., \& Verbeke, W. (2004). Using the job demands-resources model to predict burnout and performance. Human Resource Management, 43 (1), 83-104;

Bakker, A. B., \& Schaufeli, W. B. (2008). Positive organizational behavior: Engaged employees in flourishing organizations. Journal of Organizational Behavior, 29(2), 147-154.

Bakker, A. B., Schaufeli, W. B., Leiter, M. P., \& Taris, T. W. (2008). Work engagement: An emerging concept in occupational health psychology. Work \& Stress, 22(3), 187-200.

Baumruk, R. (2006). Why managers are crucial to increasing engagement: Identifying steps managers can take to engage their workforce. Strategic HR Review, 5(2), 24-27.

Baron, R. M., \& Kenny, D. A. (1986). The moderator-mediator variable distinction in social psychological research: Conceptual, strategic, and statistical considerations. Journal of personality and social psychology, 51(6), 1173.

Bass, B. M. (1991). From transactional to transformational leadership: Learning to share the vision. Organizational dynamics, 18(3), 19-31.

Bass, B. M. (1999). Two decades of research and development in transformational leadership. European journal of work and organizational psychology, 8(1), 9-32.

Bijl, D. (2009). Aan de slag met het nieuwe werken. Par CC. Zeewolde

Blok, M. M., Groenesteijn, L., Schelvis, R., \& Vink, P. (2012). New ways of working: does flexibility in time and location of work change work behavior and affect business outcomes?. Work: A Journal of Prevention, Assessment and Rehabilitation, 41, 50755080 .

Blok, M., Groenesteijn, L., Van Den Berg, C., \& Vink, P. (2011). New ways of working: A proposed framework and literature review. In Ergonomics and Health Aspects of Work with Computers (pp. 3-12). Springer Berlin Heidelberg.

Breevaart, K., Bakker, A., Hetland, J., Demerouti, E., Olsen, O. K., \& Espevik, R. (2014). Daily transactional and transformational leadership and daily employee engagement. Journal of occupational and organizational psychology,87(1), 138-157.

Cooper, C. D., \& Kurland, N. B. (2002). Telecommuting, professional isolation, and employee 
development in public and private organizations. Journal of Organizational Behavior, 23(4), 511-532.

Deci, E. L., Ryan, R. M., Gagné, M., Leone, D. R., Usunov, J., \& Kornazheva, B. P. (2001). Need satisfaction, motivation, and well-being in the work organizations of a former eastern bloc country: A cross-cultural study of self-determination. Personality and Social Psychology Bulletin, 27(8), 930-942.

De Leede, J., \& Kraijenbrink, J. (2014). The Mediating Role of Trust and Social Cohesion in the Effects of New Ways of Working: A Dutch Case Study. Human Resource Management, Social Innovation and Technology (Advanced Series in Management, Volume 14) Emerald Group Publishing Limited, 14, 3-20.

Demerouti, E., Bakker, A. B., de Jonge, J., Janssen, P. P. M., \& Schaufeli, W. B. (2001). Burnout and engagement at work as a function of demands and control. Scandinavian Journal of Work Environment and Health, 27, 279 -286.

Demerouti, E., Derks, D., Brummelhuis, L., \& Bakker, A. B. (2014). New Ways of Working: Impact on Working Conditions, Work-Family Balance, and Well-Being. In The Impact of ICT on Quality of Working Life (pp. 123-141). Springer Netherlands.

De Jonge, J., Landeweerd, J. A., \& Van Breukelen, G. J. P., (1994). De Maastrichtse autonomielijst: achtergrond, constructie en validering [The Maastricht autonomy questionnaire: background, construction and validation]. Gedrag en Organisatie, 7 (1), 27-41;

De Souza e Silva, A., (2006). From Cyber to Hybrid Mobile Technologies as Interfaces of Hybrid Spaces. Space and culture, 9(3), 261-278.

Duxbury, L., \& Neufeld, D. (1999). An empirical evaluation of the impacts of telecommuting on intra-organizational communication. Journal of Engineering and Technology Management, 16(1), 1-28.

Gajendran, R. S., \& Harrison, D. A. (2007). The good, the bad, and the unknown about telecommuting: Meta-analysis of psychological mediators and individual consequences. Journal of Applied Psychology, 92(6), 1524.

Graham, S. (2004). Beyond the 'dazzling light': from dreams of transcendence to the 'remediation' of urban life. New Media and Society, 6(1), 16-25.

Golden, T. D. (2006). The role of relationships in understanding telecommuter satisfaction. Journal of Organizational Behavior, 27(3), 319-340.

Hakanen, J. J., \& Schaufeli, W. B. (2012). Do burnout and work engagement predict depressive symptoms and life satisfaction? A three-wave seven-year prospective study. Journal of Affective Disorders, 141(2), 415-424.

Halford, S. (2005). Hybrid workspace: Re-spatialisations of work, organisation and management. New Technology, Work and Employment, 20(1), 19-33.

Harter, J., Schmidt, F. and Hayes, T. (2002). Business-unit level relationship between employee satisfaction, work engagement, and business outcomes: a meta-analysis. Journal of Applied Psychology, Vol. 87, pp. 268-79.

Hofstede, G. (1980). Culture's consequences: International differences in work-related values. Beverly Hills CA: Sage Publications.

Kilgore, K. L., \& Griffin, C. C. (1998). Beginning special educators: Problems of practice and the influence of school context. Teacher Education and Special Education: The Journal of the Teacher Education Division of the Council for Exceptional Children, 21(3), 155173.

Mauno, S., Kinnunen, U., \& Ruokolainen, M. (2007). Job demands and resources as antecedents 
of work engagement: A longitudinal study. Journal of Vocational Behavior, 70(1), 149171.

Markos, S., \& Sridevi, M. S. (2010). Employee engagement: The Key to Improving Performance. International Journal of Business \& Management, 5(12).

Miller, M., Brownell, M., \& Smith, S. (1999). Factors that predict teachers staying in, leaving, or transferring from the special education classroom. Exceptional Children. 65(2), 201-218.

Morganson, V. J., Major, D. A., Oborn, K. L., Verive, J. M., \& Heelan, M. P. (2010). Comparing telework locations and traditional work arrangements: Differences in work-life balance support, employee satisfaction, and inclusion. Journal of Managerial Psychology, 25(6), 578-595.

Muhammad, S. (2007). Future urbanization patterns: in the Netherlands, under the influence of information and communication technologies. Koninklijk Nederlands Aardrijkskundig Genootschap.

Peters, P., Poutsma, E., Van der Heijden, B. I., Bakker, A. B., \& Bruijn, T. D. (2014). Enjoying New Ways to Work: An HRM-Process Approach to Study Flow. Human Resource Management, 53(2), 271-290.

Peterson, R. (1994) A meta-analysis of Cronbach's coefficient alpha. Journal of Consumer Research, 21, 381-91.

Preacher, K. J., \& Hayes, A. F. (2008). Asymptotic and resampling strategies for assessing and comparing indirect effects in multiple mediator models. Behavior research methods, 40(3), 879-891.

Prusak, L. (2001). In good company: How social capital makes organizations work. Harvard Business Press, Chicago.

Reynaarde talent ontwikkeling (2013). Flexibele arbeidsrelaties; my size fits me. retrieved July 15, 2013, from: http://www.reynaarde.nl/talentontwikkeling/flexibelearbeidsrelaties.html.

Robbins, S. P., \& Judge, T. (2007). Organizational behavior. Upper Saddle River, N.J: Pearson/Prentice Hall.

Rosenberg, M. S., O'Shea, L. J., \& O'Shea, D. J. (1998). Student teacher to master teacher: A practical guide for educating students with special needs. Upper Saddle River, NJ: Merrill.

Rothbard, N. P. (2001). Enriching or depleting? The dynamics of engage- ment in work and family roles. Administrative Science Quarterly, 46, 655- 684.

Rowden, R.W. (2000). "The relationship between charismatic leadership behaviors and organizational commitment". Leadership \& Organization Development Journal, Vol. 21 Iss: 1 , pp.30 - 35 .

Saks, A. M. (2006). Antecedents and consequences of work engagement. Journal of Managerial Psychology, 21(7), 600-619.

Salanova, M., Agut, S., \& Peiro, J. M. (2005). Linking organizational resources and work engagement to employee performance and customer loyalty: the mediation of service climate. Journal of applied Psychology, 90(6), 1217-1227.

Schaufeli, W. B., \& Bakker, A. B. (2003). Test manual for the Utrecht Work engagement Scale. Unpublished manuscript, Utrecht University, the Netherlands. Retrieved from http://www.schaufeli.com.

Schaufeli, W.B., Salanova, M., Gonzalez-Roma, V., \& Bakker, A.B. (2002). The measurement of engagement and burnout: a two sample confirmatory factor analytic approach. Journal of happiness studies, 3, 71-91. 
Ten Brummelhuis, L. L., Bakker, A. B., Hetland, J., \& Keulemans, L. (2012). Do new ways of working foster work engagement? Psicothema, 24(1), 113-120.

Truss, C., Shantz, A., Soane, E., Alfes, K., \& Delbridge, R. (2013). Employee engagement, organisational performance and individual well-being: exploring the evidence, developing the theory. The international Journal of Human Resource Management, 24(14), 26572669.

Veldhoven, M. J. P. M., \& Meijman, T. F. (1994). Het meten van psychosociale arbeidsbelasting met een vragenlijst: de vragenlijst beleving en beoordeling van de arbeid (VBBA) [The measurement of psychosocial strain at work: The questionnaire experience and evaluation of work]. Amsterdam: Nederlands Instituut voor Arbeidsomstandigheden NIA.

Yalabik, Z., van Rossenberg, Y. G. T., Swart, J., \& Kinnie, N. (forthcoming). Engaged and committed? The relationship between employee engagement and commitment in Professional Service Firms. The International Journal of Human Resource Management.

Zhu, W., Avolio, B. J., \& Walumbwa, F. O. (2009). Moderating role of follower characteristics with transformational leadership and follower work engagement. Group \& Organization Management, 34(5), 590-619. 
Figure 1. Overview of our hypothesized relationships between NWW facets and work engagement.

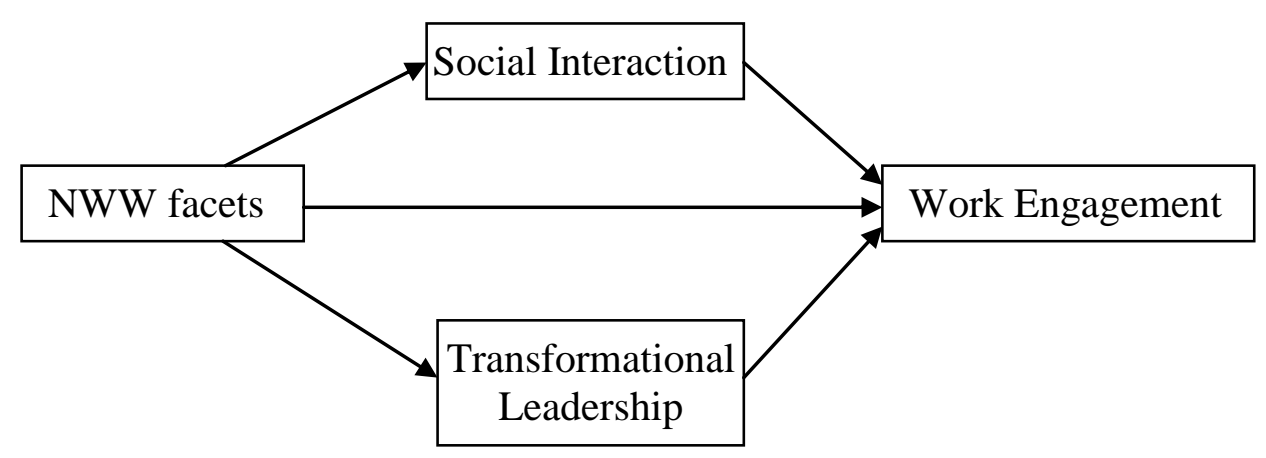

Figure 2. Multiple mediation framework for NWW on Work Engagement. Unstandardized regression coefficients of (A) Total effect and (B) Direct ( $\left.c^{\prime}\right)$ and indirect effects $\left(a_{i} b_{i}\right)$.

A.

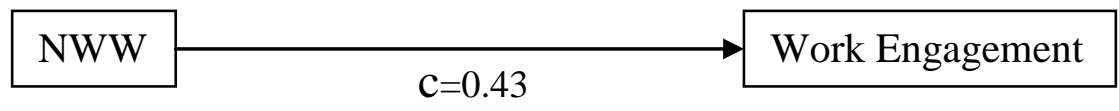

B.

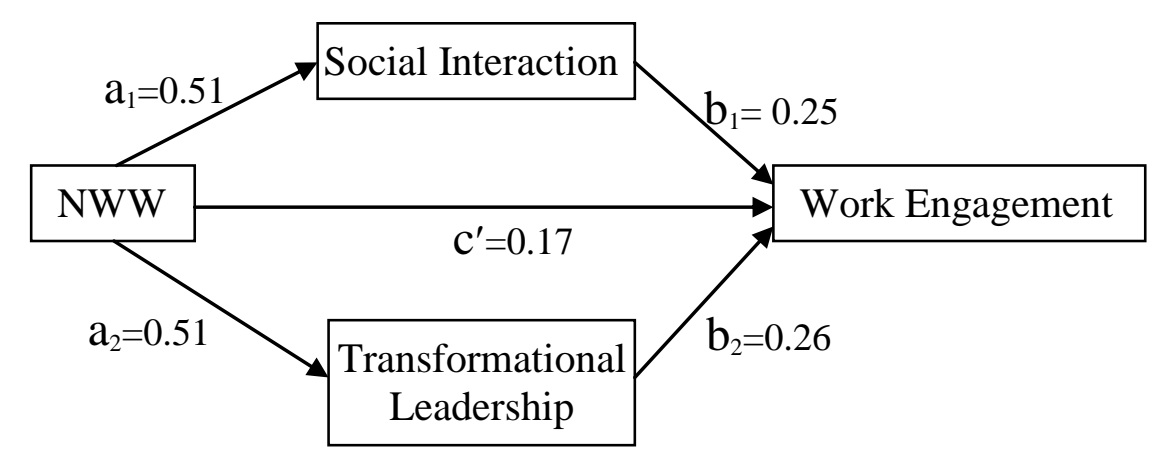

Note: (A) Total effect $\mathrm{c}=\Sigma\left(\mathrm{a}_{\mathrm{i}} \mathrm{b}_{\mathrm{i}}\right)+\mathrm{c}^{\prime}$; (B) P-values of coefficients are all significant at the $1 \%$ level. 
Table 1. Internal consistencies and correlations between the variables $(N=656)$

\begin{tabular}{lccccccccc}
\hline & 1 & 2 & 3 & 4 & 5 & 6 & 7 & 8 & 9 \\
\hline 1. Work engagement & $.94)$ & & & & & & & & \\
2. New Ways of Working (aggregate) & .33 & $(.86)$ & & & & & & & \\
3. NWW Facet 1: Anytime, anywhere & .19 & .71 & $(.79)$ & & & & & & \\
4. NWW Facet 2: Manage your own work & .30 & .66 & .55 & & & & & & \\
5. NWW Facet 3: Unlimited access and connectivity & .29 & .85 & .35 & .44 & $(.76)$ & & & & \\
6. NWW Facet 4: My size fits me & .20 & .73 & .71 & .50 & .43 & & & & \\
7. NWW Facet 5: Open workplace & .25 & .70 & .24 & .32 & .60 & .29 & $(.77)$ & & \\
8. Social Interaction & .44 & .46 & .17 & .22 & .51 & .24 & .40 & $(.74)$ \\
9. Transformational leadership & .45 & .45 & .30 & .28 & .37 & .31 & .39 & .54 & $(.92)$ \\
\hline
\end{tabular}

Cronbach's alphas on the diagonal

All correlations are significant at $\mathrm{P}<.001$ 
Table 2. OLS estimates of individual facets of NWW, social interaction, transformational leadership and work engagement

\begin{tabular}{|c|c|c|c|c|c|c|c|c|}
\hline & \multirow{2}{*}{$\begin{array}{c}\begin{array}{c}\text { Social } \\
\text { Interaction }\end{array} \\
1\end{array}$} & \multirow{2}{*}{$\begin{array}{c}\begin{array}{c}\text { Transformational } \\
\text { Leadership }\end{array} \\
2\end{array}$} & \multicolumn{3}{|c|}{ Work Engagement } & \multicolumn{3}{|c|}{ Work Engagement } \\
\hline & & & 3 & 4 & 5 & 6 & 7 & 8 \\
\hline Anytime, anywhere & $\begin{array}{c}0.019 \\
(0.054)\end{array}$ & $\begin{array}{c}0.189^{* * *} \\
(0.057)\end{array}$ & & & $\begin{array}{c}0.079 \\
(0.059)\end{array}$ & $\begin{array}{c}0.072 \\
(0.055)\end{array}$ & $\begin{array}{l}0.010 \\
(0.055)\end{array}$ & $\begin{array}{c}0.025 \\
(0.054)\end{array}$ \\
\hline Manage your own work & $\begin{array}{l}-0.028 \\
(0.043)\end{array}$ & $\begin{array}{c}0.023 \\
(0.046)\end{array}$ & & & $\begin{array}{c}0.170 * * * \\
(0.047)\end{array}$ & $\begin{array}{c}0.181 * * * \\
(0.044)\end{array}$ & $\begin{array}{c}0.162 * * * \\
(0.044)\end{array}$ & $\begin{array}{c}0.172 * * * \\
(0.043)\end{array}$ \\
\hline Unlimited access and connectivity & $\begin{array}{c}0.445^{* * *} * \\
(0.048)\end{array}$ & $\begin{array}{c}0.165^{* * *} \\
(0.051)\end{array}$ & & & $\begin{array}{c}0.181 * * * \\
(0.052)\end{array}$ & $\begin{array}{c}0.011 \\
(0.052)\end{array}$ & $\begin{array}{c}0.121 * * \\
(0.049)\end{array}$ & $\begin{array}{c}0.020 \\
(0.051)\end{array}$ \\
\hline My size fits me & $\begin{array}{c}0.050 \\
(0.046)\end{array}$ & $\begin{array}{c}0.070 \\
(0.049)\end{array}$ & & & $\begin{array}{c}0.022 \\
(0.050)\end{array}$ & $\begin{array}{c}0.003 \\
(0.047)\end{array}$ & $\begin{array}{l}-0.004 \\
(0.047)\end{array}$ & $\begin{array}{l}-0.010 \\
(0.045)\end{array}$ \\
\hline Open workplace & $\begin{array}{c}0.152 * * * \\
(0.042)\end{array}$ & $\begin{array}{c}0.245^{* * *} * \\
(0.044)\end{array}$ & & & $\begin{array}{c}0.128 * * * \\
(0.045)\end{array}$ & $\begin{array}{c}0.069 \\
(0.043)\end{array}$ & $\begin{array}{c}0.039 \\
(0.044)\end{array}$ & $\begin{array}{c}0.024 \\
(0.042)\end{array}$ \\
\hline Social Interaction & & & $\begin{array}{c}0.471 * * * \\
(0.036)\end{array}$ & & & $\begin{array}{c}0.383 * * * \\
(0.041)\end{array}$ & & $\begin{array}{c}0.268 * * * \\
(0.044)\end{array}$ \\
\hline Transformational leadership & & & & $\begin{array}{c}0.467 * * * \\
(0.035)\end{array}$ & & & $\begin{array}{c}0.364 * * * \\
(0.039)\end{array}$ & $\begin{array}{c}0.256^{* * * *} \\
(0.042)\end{array}$ \\
\hline Age: $18-34$ & & & & Reference & & & & \\
\hline Age: $35-49$ & $\begin{array}{c}0.115 \\
(0.098)\end{array}$ & $\begin{array}{l}-0.157 \\
(0.104)\end{array}$ & $\begin{array}{c}0.080 \\
(0.103)\end{array}$ & $\begin{array}{l}0.180^{*} \\
(0.103)\end{array}$ & $\begin{array}{c}0.123 \\
(0.107)\end{array}$ & $\begin{array}{c}0.082 \\
(0.100)\end{array}$ & $\begin{array}{l}0.184^{*} \\
(0.100)\end{array}$ & $\begin{array}{c}0.136 \\
(0.098)\end{array}$ \\
\hline Age: $50-67$ & $\begin{array}{l}-0.043 \\
(0.100)\end{array}$ & $\begin{array}{l}-0.015 \\
(0.105)\end{array}$ & $\begin{array}{c}0.396 * * * \\
(0.104)\end{array}$ & $\begin{array}{c}0.358 * * * \\
(0.103)\end{array}$ & $\begin{array}{c}0.391 * * * \\
(0.108)\end{array}$ & $\begin{array}{c}0.407 * * * \\
(0.101)\end{array}$ & $\begin{array}{c}0.396 * * * \\
(0.101)\end{array}$ & $\begin{array}{c}0.406 * * * \\
(0.098)\end{array}$ \\
\hline Gender: 1 if female & $\begin{array}{l}-0.006 \\
(0.076)\end{array}$ & $\begin{array}{c}0.069 \\
(0.081)\end{array}$ & $\begin{array}{c}0.046 \\
(0.080)\end{array}$ & $\begin{array}{c}0.014 \\
(0.079)\end{array}$ & $\begin{array}{c}0.086 \\
(0.083)\end{array}$ & $\begin{array}{c}0.088 \\
(0.078)\end{array}$ & $\begin{array}{c}0.061 \\
(0.078)\end{array}$ & $\begin{array}{c}0.070 \\
(0.076)\end{array}$ \\
\hline Education: Primary and lower (vocational) level & & & & Reference & & & & \\
\hline Education: Intermediate level vocational education (MBO) & $\begin{array}{l}-0.147 \\
(0.113)\end{array}$ & $\begin{array}{l}-0.048 \\
(0.119)\end{array}$ & $\begin{array}{c}0.156 \\
(0.119)\end{array}$ & $\begin{array}{c}0.111 \\
(0.118)\end{array}$ & $\begin{array}{c}0.093 \\
(0.123)\end{array}$ & $\begin{array}{c}0.149 \\
(0.115)\end{array}$ & $\begin{array}{c}0.111 \\
(0.115)\end{array}$ & $\begin{array}{c}0.145 \\
(0.112)\end{array}$ \\
\hline Education: High school & $\begin{array}{c}0.006 \\
(0.129)\end{array}$ & $\begin{array}{c}-0.220 \\
(0.136)\end{array}$ & $\begin{array}{l}-0.048 \\
(0.135)\end{array}$ & $\begin{array}{c}0.071 \\
(0.134)\end{array}$ & $\begin{array}{c}-0.052 \\
(0.140)\end{array}$ & $\begin{array}{c}-0.054 \\
(0.131)\end{array}$ & $\begin{array}{c}0.028 \\
(0.131)\end{array}$ & $\begin{array}{c}-0.003 \\
(0.128)\end{array}$ \\
\hline Education: Higher vocational/Bachelor level & $\begin{array}{l}-0.097 \\
(0.119)\end{array}$ & $\begin{array}{l}-0.141 \\
(0.126)\end{array}$ & $\begin{array}{l}-0.030 \\
(0.124)\end{array}$ & $\begin{array}{l}-0.010 \\
(0.123)\end{array}$ & $\begin{array}{l}-0.143 \\
(0.129)\end{array}$ & $\begin{array}{l}-0.106 \\
(0.121)\end{array}$ & $\begin{array}{l}-0.091 \\
(0.121)\end{array}$ & $\begin{array}{l}-0.081 \\
(0.118)\end{array}$ \\
\hline Education: University: Master level & $\begin{array}{c}-0.282 * * \\
(0.142)\end{array}$ & $\begin{array}{l}-0.179 \\
(0.150)\end{array}$ & $\begin{array}{c}0.012 \\
(0.147)\end{array}$ & $\begin{array}{l}-0.035 \\
(0.147)\end{array}$ & $\begin{array}{l}-0.228 \\
(0.154)\end{array}$ & $\begin{array}{l}-0.120 \\
(0.145)\end{array}$ & $\begin{array}{l}-0.163 \\
(0.145)\end{array}$ & $\begin{array}{l}-0.107 \\
(0.141)\end{array}$ \\
\hline Sector dummies & Yes & Yes & Yes & Yes & Yes & Yes & Yes & Yes \\
\hline Occupation dummies & Yes & Yes & Yes & Yes & Yes & Yes & Yes & Yes \\
\hline Constant & $\begin{array}{c}-0.225 \\
(0.371) \\
\end{array}$ & $\begin{array}{c}-0.024 \\
(0.393) \\
\end{array}$ & $\begin{array}{c}0.291 \\
(0.320) \\
\end{array}$ & $\begin{array}{c}0.133 \\
(0.319) \\
\end{array}$ & $\begin{array}{c}-0.396 \\
(0.403) \\
\end{array}$ & $\begin{array}{c}-0.309 \\
(0.378) \\
\end{array}$ & $\begin{array}{c}-0.387 \\
(0.377) \\
\end{array}$ & $\begin{array}{c}-0.329 \\
(0.367) \\
\end{array}$ \\
\hline $\mathrm{N}$ & 656 & 656 & 656 & 656 & 656 & 656 & 656 & 656 \\
\hline R-squared & 0.33 & 0.26 & 0.26 & 0.27 & 0.22 & 0.32 & 0.32 & 0.36 \\
\hline
\end{tabular}

Standard errors in parentheses. $* * * \mathrm{p}<0.01, * * \mathrm{p}<0.05, * \mathrm{p}<0.1$ 
Appendix A - Questionnaire

\begin{tabular}{|c|c|c|}
\hline Variabele & \multicolumn{2}{|l|}{ Statements } \\
\hline \multicolumn{3}{|l|}{ Work engagement } \\
\hline & $\begin{array}{l}\text { At my work, I feel bursting with energy } \\
\text { At my job, I feel strong and vigorous } \\
\text { I am enthusiastic about my job } \\
\text { My job inspires me } \\
\text { When I get up in the morning, I feel like going to work } \\
\text { I feel happy when I am working intensely } \\
\text { I am proud on the work that I do } \\
\text { I am immersed in my work } \\
\text { I get carried away when I'm working }\end{array}$ & $\begin{array}{l}\text { (1) never - (7) Always } \\
\text { (1) never - (7) Always } \\
\text { (1) never - (7) Always } \\
\text { (1) never - (7) Always } \\
\text { (1) never - (7) Always } \\
\text { (1) never - (7) Always } \\
\text { (1) never - (7) Always } \\
\text { (1) never - (7) Always } \\
\text { (1) never - (7) Always }\end{array}$ \\
\hline \multicolumn{3}{|l|}{ New Ways of Working } \\
\hline Facet 1: Anytime, anywhere & $\begin{array}{l}\text { I am able to set my own working hours } \\
\text { I am able to determine where I work }\end{array}$ & $\begin{array}{l}\text { (1) not at all - (5) To a high degree } \\
\text { (1) not at all - (5) To a high degree }\end{array}$ \\
\hline $\begin{array}{l}\text { Facet 2: Manage your own work } \\
\text { Facet 3: Unlimited access and } \\
\text { connectivity }\end{array}$ & $\begin{array}{l}\text { I am able to determine the way I work } \\
\text { I can access all necessary information on my computer, } \\
\text { smartphone, and/or tablet } \\
\text { I am able to reach colleagues within the team quickly } \\
\text { I am able to reach managers quickly } \\
\text { I am able to reach colleagues outside the team quickly }\end{array}$ & $\begin{array}{l}\text { (1) not at all - (5) To a high degree } \\
\text { (1) not at all - (5) To a high degree } \\
\text { (1) not at all - (5) To a high degree } \\
\text { (1) not at all - (5) To a high degree } \\
\text { (1) not at all - (5) To a high degree }\end{array}$ \\
\hline $\begin{array}{l}\text { Facet 4: My size fits me } \\
\text { Facet 5: Open workplace }\end{array}$ & $\begin{array}{l}\text { I have the ability to adapt my working scheme to my phase } \\
\text { of life and ambitions. } \\
\text { the building is arranged so that colleagues are easily } \\
\text { accessible } \\
\text { The building is arranged so that managers are easily } \\
\text { accessible }\end{array}$ & $\begin{array}{l}\text { (1) not at all - (5) To a high degree } \\
\text { (1) not at all - (5) To a high degree } \\
\text { (1) not at all - (5) To a high degree }\end{array}$ \\
\hline \multicolumn{3}{|l|}{ Social interaction } \\
\hline & $\begin{array}{l}\text { I find working with my colleagues pleasant } \\
\text { When facing problems I quickly receive help from } \\
\text { colleagues } \\
\text { When facing problems I quickly receive help from my } \\
\text { manager } \\
\text { 'Communication by means of face-to-face contact is } \\
\text { important to maintain a good working relationship' }\end{array}$ & $\begin{array}{l}\text { (1) not at all - (5) To a high degree } \\
\text { (1) not at all - (5) To a high degree } \\
\text { (1) not at all - (5) To a high degree } \\
\text { (1) not at all - (5) To a high degree }\end{array}$ \\
\hline \multicolumn{3}{|l|}{ Transformational leadership } \\
\hline & $\begin{array}{l}\text { My supervisor gives a clear image of his strategic vision. } \\
\text { My supervisor exhibits desirable behaviour within the } \\
\text { organisation. } \\
\text { My supervisor acts as a role model within te organisation. } \\
\text { My supervisor provides guidance when I need it. } \\
\text { My supervisor inspires and motivates employees. } \\
\text { My supervisor stimulates the intellect of employees. } \\
\text { My supervisor considers the individual. } \\
\text { My supervisor stimulates the development of employees. } \\
\text { My supervisor allows employees to foster working } \\
\text { relationships. } \\
\text { My supervisor works overtime. } \\
\text { My supervisor contacts me outside office hours. } \\
\text { My supervisor rewards outcomes rather than the way I work. }\end{array}$ & $\begin{array}{l}\text { (1) not at all - (5) To a high degree } \\
\text { (1) not at all - (5) To a high degree } \\
\text { (1) not at all - (5) To a high degree } \\
\text { (1) not at all - (5) To a high degree } \\
\text { (1) not at all - (5) To a high degree } \\
\text { (1) not at all - (5) To a high degree } \\
\text { (1) not at all - (5) To a high degree } \\
\text { (1) not at all - (5) To a high degree } \\
\text { (1) not at all - (5) To a high degree } \\
\text { (1) not at all - (5) To a high degree }\end{array}$ \\
\hline
\end{tabular}


Appendix B - Characteristics of sample (N=656)

\begin{tabular}{|l|l|c|c|}
\hline Grouping variable & Category & Respondents (N) & Percentage (\%) \\
\hline Gender & Male & 303 & 46.2 \\
& Female & 353 & 53.8 \\
\hline Age & $18-34$ & 116 & 17.7 \\
& $35-49$ & 249 & 37.9 \\
& $50-67$ & 291 & 44.4 \\
\hline Education & Primary school an lower (vocational) level & 87 & 13.3 \\
& Intermediate vocational education (MBO) & 181 & 27.6 \\
& High school & 90 & 13.7 \\
& Higher vocational education/bachelor level & 210 & 32.0 \\
& University education(Master level) & 88 & 13.4 \\
\hline Occupational field & Pedagogical & 63 & 9.6 \\
& Creative & 11 & 1.7 \\
& Agricultural & 1 & 0.2 \\
& Technical and industrial & 68 & 10.4 \\
& Transport & 24 & 3.7 \\
& Medical and paramedical & 50 & 7.6 \\
& Economic-administrative & 158 & 24.1 \\
& ICT & 57 & 8.7 \\
& Socio-cultural & 21 & 3.2 \\
& Caring and service & 60 & 9.2 \\
& Public order and safety & 18 & 27 \\
& Other & 125 & 19.1 \\
\hline Sector of Industry & Agriculture, forestry and fisheries & 4 & 0.6 \\
& Construction & 15 & 2.3 \\
& Industry & 72 & 11.0 \\
& Retail & 36 & 5.5 \\
& Financial services & 52 & 7.9 \\
& Wholesale & 31 & 4.7 \\
& Hospitality & 10 & 1.5 \\
& Personal services & 18 & 2.7 \\
& Transport & 44 & 6.7 \\
& Commercial services & 137 & 20.9 \\
& Healthcare & 104 & 15.9 \\
& Education & 32 & 12.7 \\
& Social services & 18 & 4.9 \\
& Other & 2.7 \\
\hline
\end{tabular}


Appendix C - Mediation of the effect of NWW on work engagement through social interaction and transformational leadership.

\begin{tabular}{|c|c|c|c|c|c|c|}
\hline & & & & $95 \%$ & erval & \\
\hline & Coefficient & SE & $\mathrm{Z}$ & Lower & Upper & \\
\hline Indirect effects: & & & & & & \\
\hline Social Interaction $\left(a_{1} b_{1}\right)$ & 0.1263 & 0.0257 & 4.92 & 0.0764 & 0.1772 & $(\mathrm{P})$ \\
\hline & & & & 0.0815 & 0.1824 & (BC) \\
\hline & & & & 0.0818 & 0.1838 & (BCa) \\
\hline Transf. Lead. $\left(a_{2} b_{2}\right)$ & 0.1316 & 0.0244 & 5.40 & 0.0834 & 0.1777 & $(\mathrm{P})$ \\
\hline & & & & 0.0868 & 0.1810 & $(\mathrm{BC})$ \\
\hline & & & & 0.0871 & 0.1816 & (BCa) \\
\hline Total indirect & 0.2579 & 0.0316 & 8.16 & 0.1930 & 0.3181 & $(\mathrm{P})$ \\
\hline & & & & 0.1993 & 0.3255 & $(\mathrm{BC})$ \\
\hline & & & & 0.2013 & 0.3286 & (BCa) \\
\hline
\end{tabular}

Note: P, percentile; $\mathrm{BC}$, bias corrected; $\mathrm{BCa}$, bias corrected and accelerated; 5,000 bootstrap samples 